\title{
SEASONALITY IN LITTERFALL PRODUCTION IN A NATIVE FOREST IN THE CENTRAL REGION OF RS, BRAZIL
}

\author{
Hamilton Luiz Munari Vogel ${ }^{1 *}$, Monique Pimentel Lagemann², Mauro Valdir Schumacher ${ }^{3}$ \\ 1*Universidade Federal do Pampa, Campus São Gabriel, São Gabriel, RS, Brazil - email (*hamiltonvogel@ gmail.com) \\ ${ }^{2}$ Universidade Federal de Santa Maria, Master Science degree by Forest Engineer Post-Graduation Program, Santa Maria, RS, Brazil - email \\ (moniquelagemann@gamil.com) \\ ${ }^{3}$ Universidade Federal de Santa Maria, Departamento de Ciências Florestais, Santa Maria, RS, Brazil - email (mvschumacher@ gmail.com)
}

Received for publication: 21/01/2019 - Accepted for publication: 24/09/2020

\begin{abstract}
Resumo
Sazonalidade na produção de serapilheira em uma floresta nativa na Região Central do RS, Brasil. Os estudos com deposição de serapilheira são considerados um importante indicador da qualidade ambiental de ecossistemas florestais, constituindo a principal via de entradas de matéria orgânica e nutrientes para as florestas. $\mathrm{O}$ presente estudo teve como principal objetivo, quantificar a produção anual de serapilheira e sua sazonalidade em um fragmento de Floresta Estacional Semidecidual, localizado na região da Depressão Central do Estado do Rio Grande do Sul, no município de São Sepé. No interior desta floresta, em um local com condições homogêneas, foram alocadas de forma sistemática cinco parcelas de $20 \mathrm{~m}$ x $15 \mathrm{~m}$, com 30 metros de distância entre si, onde foram distribuídos cinco coletores de serapilheira $\left(0,1963 \mathrm{~m}^{2}\right.$ por coletor), totalizando 25 coletores. A coleta de todo o material vegetal depositado pelas árvores nos coletores foi realizada mensalmente por um período de quatro anos. No laboratório, as amostras foram separadas nas frações folhas, galhos finos (diâmetro $<0,5 \mathrm{~cm}$ ) e miscelânea, após, foram secas em estufa e pesadas em balança de precisão. Verificou-se maior deposição de serapilheira na primavera, com os maiores picos de devolução principalmente no mês de outubro, indicando um comportamento sazonal de deposição. A deposição média de serapilheira foi de $6,56 \mathrm{Mg} \mathrm{ha}^{-1} \mathrm{ano}^{-1}$; deste total as folhas foram responsáveis por $67,61 \%$, seguido da miscelânea com 19,04\% e dos galhos finos com 13,29\%. Somente foi obtida uma correlação significativa alta entre a fração miscelânea e a temperatura.

Palavras-chave: deposição de folhas; ciclagem de nutrientes; Floresta Estacional Semidecidual.
\end{abstract}

\begin{abstract}
Seasonality in litterfall production in a native forest in the central region, Brazil. Studies on litter deposition are considered an important indicator of environmental quality of forest ecosystems. It is the main route of entry of organic matter and nutrients to forests. The objective of this study was to quantify the annual litterfall and seasonality in a fragment of native forest located in São Sepé in the Central Depression of Rio Grande do Sul. The experiment was conducted in a fragment of a Seasonal Semideciduous Forest. Inside this forest, in a place with homogeneous conditions, five plots of $20 \mathrm{~m} \mathrm{x} 15 \mathrm{~m}$ length were systematically allocated 30 meters away from each other, where five litterfall traps were distributed in each plot $\left(0,1963 \mathrm{~m}^{2}\right.$ each trap), totaling 25 traps. The collection of all plant material deposited by the trees in the collectors was performed monthly in a four-year period. In the laboratory, the samples were separated into leaves, small twigs (diameter $<0.5 \mathrm{~cm}$ ) and miscellaneous, and after they were oven dried and weighed on a precision balance. Higher litterfall was observed in the spring, with the highest return peaks mainly in October, indicating a seasonal deposition behavior. The mean litterfall was $6.56 \mathrm{Mg} \mathrm{ha}^{-1}$ year-1; $^{-1}$ of this total, the leaves were responsible for $67.61 \%$, followed by the miscellaneous with $19.04 \%$ and the small twigs with $13.29 \%$. Only a high significant correlation was obtained between the miscellaneous fraction and the temperature.

Keywords: leaf deposition; nutrient cycling; Seasonal Semideciduous Forest.
\end{abstract}

\section{INTRODUCTION}

The state of Rio Grande do Sul is known for its important agricultural activity, mainly extensive livestock, with a large occurrence of extensive soybean and rice crops, which generate great environmental impacts on native ecosystems, with considerable reduction of their habitats. In the Central Depression region of the state it is no different as there are currently few remnants of native forests, which are very disturbed and need to be better studied in order to be restored and preserved. In this region, the native forest of the Subtropical Seasonal-type predominates, which currently occurs in the form of fragments, with different levels of impact and degradation, where few studies with nutrient cycling have been developed, such as those by Schumacher $e t a l$. (2018); Cunha et al. (1993); König et al. (2002) and Vogel et al., (2007).

Thus, in studies of nutrient cycling, according to Schumacher and Viera (2015), the production of litter and the return of nutrients in forest ecosystems constitute the most important path of the biogeochemical cycle

FLORESTA, Curitiba, PR, v. 51, n. 1, p. 019-027, jan/mar 2021.

Vogel, H. L. M. et.al.

ISSN eletrônico 1982-4688

DOI: 10.5380/rf.v51 i1. 64443 
(nutrient flow in the soil-plant-soil system). Also, according to the same authors, this cycle, together with the biochemical (circulation of nutrients inside the plant), allows forest trees to synthesize organic matter through photosynthesis, mainly by recycling nutrients in highly weathered soils, where plant biomass is its main reservoir.

For this reason, its quantification is an important indicator of the amount of nutrients that enter the forest annually and their stock in the soil. Calvi et al. (2009) emphasize that the organic material that is continuously deposited on the soil assumes undeniable importance in maintaining fertility and nutrient levels in the soil, since the litter assumes the role of potential nutrient stock for the system. In this sense, litter formed in the interior of the forests is considered the most important route of nutrient cycling, as it is responsible for the largest amount of organic material that is deposited in the forest soil, and its determination allows to analyze the restructuring of anthropized forest environments (NASCIMENTO et al., 2018).

The litter deposited in the soil is formed mostly by leaves that are more easily decomposed, thin and thick branches and residues of different shapes, such as flowers, fruits, seeds and plant and animal waste of different sizes that are difficult to be identified. The amount of litter deposited over the years on the forest floor varies widely according to the type of forest, climatic conditions and soils. Bray and Gorham (1964) have already emphasized the great influence of regions and temperatures in the deposition of litter; the authors claim that the most productive are the equatorial forests with about 11 tons of litter per hectare per year, followed by the warm temperate forests with 5.5 tons, cold temperate forests, 3.5 tons, and the ones that produce less are those in the arctic or alpine regions with an average of one ton per hectare per year. This amount deposited on the soil, depending on the type of forest, can reach several tons per hectare annually, according to some studies carried out in Deciduous and Semideciduous Seasonal Forests in southern Brazil (SCHUMACHER et al., 2018); (TOSCAN et al., 2017); (DICK et al., 2015); (VOGEL et al., 2007); (KÖNIG et al., 2002).

In this context, Viera et al. (2010), emphasize that studies in native forests are of vital importance for understanding the behavior of the characteristics intrinsic to the ecosystem. For example, for the recovery of native forests, litter is essential to restore nutrient cycling and recover soil fertility, especially in the early stages of ecological restoration (LORENZO; CAMPAGNARO, 2017), composing an important bioindicator of nutrient cycling in forest ecosystems.

In this context, in order to seek a better understanding of the contribution of litter in the supply of organic material and nutrients in forest fragments, the objective of this study was to quantify the annual production of litterfall and its seasonality in leaves, small twigs and miscellaneous fractions, for a period of four years, in a fragment of native forest of the Seasonal Semideciduous type, located in the São Sepé county in the central region of Rio Grande do Sul State, Brazil.

\section{MATERIAL AND METHODS}

The experiment was carried out in a fragment of the Seasonal Semideciduous Forest at an advanced regeneration stage in the region of the São Sepé county, central region of Rio Grande do Sul State, Brazil. The fragment is located between the coordinates $30^{\circ} 12^{\prime} 45^{\prime \prime}$ and $30^{\circ} 13^{\prime} 09 \mathrm{~S}$ and $53^{\circ} 42^{\prime} 57^{\prime \prime} \mathrm{W}$ at $200 \mathrm{~m}$ altitude, with an area of approximately 40 ha, classified as a small forest fragment (RIBEIRO et al., 2009 ), without human interference and isolated from farming activities for approximately 50 years. The native forest fragment belongs to a private soybean farm, signed through a research agreement between the Federal University of Pampa (UNIPAMPA-Campus São Gabriel) and Cooperative Tritícola Sepeense Ltda. (COTRISEL) of São Sepé county.

The climate in the region is humid-subtropical Cfa, according to the classification of Köppen, with an average annual rainfall ranging from 1.600 to $1.900 \mathrm{~mm}$, and an average annual air temperature of 18 to $20^{\circ} \mathrm{C}$ (ALVARES et al., 2014). In terms of meteorological characterization, the rainfall distribution over the experimental period was uniform with an annual average of $1.800 \mathrm{~mm}$, the peaks were from October to December, the lowest volumes were recorded in winter, with no water shortage (INMET, 2018). In the same period, the average air temperature was $20^{\circ} \mathrm{C}$, where the highest values were recorded in the months of January and February (average of $25^{\circ} \mathrm{C}$ ), and the lowest in June and July (average of $13.6^{\circ} \mathrm{C}$ ) according to data from the nearest station at $62 \mathrm{~km}$ away from the experimental site in Santa Maria county, State of Rio Grande do Sul (INMET, 2018).

The soil at the experimental site is classified as Haplic Planosol (Embrapa, 2018), with a sandy-loam surface texture on the A-horizon and low content of organic matter. For chemical characterization of the local soil, five trenches were collected, one in each litter-plot, at the $0-20 \mathrm{~cm}$ and $20-40 \mathrm{~cm}$ depths. Table 1 shows the average chemical attributes of the soil in the experimental area, according to the methodology of Tedesco et al. (1995). This table shows low levels of $\mathrm{P}$ in the soil (Table 1), average levels of $\mathrm{K}, \mathrm{Ca}$ and $\mathrm{Mg}$, high levels of $\mathrm{S}$,

FLORESTA, Curitiba, PR, v. 51, n. 1, p. 019-027, jan/mar 2021.

Vogel, H. L. M. et.al.

ISSN eletrônico 1982-4688

DOI: 10.5380/rf.v51 i1. 64443 
$\mathrm{Cu}, \mathrm{Zn}$ and $\mathrm{B}$ (CQFS, 2016). Organic matter and $\mathrm{CEC}_{\mathrm{pH} 7}$ present average values on the surface decreasing in depth, according to the reference values for forest crops (CQFS, 2016).

Table 1. Soil chemical aspects of the experimental area.

Tabela 1. Aspectos químicos do solo da área experimental.

\begin{tabular}{|c|c|c|c|c|c|c|c|c|c|}
\hline $\begin{array}{c}\text { Depth } \\
\mathrm{cm}\end{array}$ & $\begin{array}{c}\text { Clay } \\
\text {----- }\end{array}$ & OM & Texture & $\mathrm{Ca}^{2+}$ & $\mathrm{Mg}^{2+}$ & $\begin{array}{l}\mathbf{A l}^{\mathbf{3 +}} \\
\text { olc dm }\end{array}$ & H+Al & $\begin{array}{l}\mathbf{P} \\
----n\end{array}$ & $\begin{array}{l}\text { Exch. K } \\
m^{-3}---\end{array}$ \\
\hline $0-20$ & 18.0 & 2.7 & 4,0 & 3.5 & 1.0 & 0.3 & 7.7 & 6.7 & 52.0 \\
\hline $20-40$ & 19.0 & 1.3 & 4.0 & 1.5 & 0.5 & 0.7 & 5.5 & 7.9 & 28.0 \\
\hline Depth & $\mathbf{S}$ & $\mathrm{Cu}$ & Zn & $\mathbf{B}$ & $\mathbf{M}$ & $\mathbf{V}$ & $\mathrm{CEC}_{\mathrm{e}}$ & $\mathrm{CEC}_{\mathrm{pH} 7}$ & $\mathbf{P h}$ \\
\hline $\mathbf{c m}$ & \multicolumn{4}{|c|}{--------- $\mathbf{m g ~ d m}$ dm $^{-3}$} & \multicolumn{2}{|c|}{$\%$} & \multicolumn{2}{|c|}{---- cmolc dm dm $^{-3---}$} & \\
\hline $0-20$ & 14.4 & 0.54 & 2.88 & 0.4 & 6.1 & 37.4 & 4.9 & 12.3 & 4.8 \\
\hline $20-40$ & 4.5 & 0.59 & 0.59 & 0.3 & 28.0 & 24.3 & 2.5 & 7.3 & 4.9 \\
\hline
\end{tabular}

Exch. K: exchangeable K; m: Aluminum saturation index; BS: Base saturation; $\mathrm{CEC}_{\mathrm{e}}$ : Cation exchange capacity (effective); $\mathrm{CEC}_{\mathrm{pH}}$ : $\mathrm{Cation}$ exchange capacity (total)

Regarding the characterization of the floristic and structural composition, the fragment shows medium floristic diversity, presenting as species of greater importance Trichilia clausseni C.DC., Matayba elaeagnoides Radlk., Ocotea pulchella (Nees) Mez, Sorocea bonplandii (Baill.) W.C. Burger, Lanjouw \& Boer, Helietta apiculata Benth. and Sebastiania commersoniana (Baill.) L.B. Sm. \& Downs.

For the collection of the produced litterfall within the forest fragment in a place with homogeneous environmental characteristics (such as soil, size of the upper canopy trees and small slopes), five traps of $20 \mathrm{~m} \mathrm{x}$ $15 \mathrm{~m}$ each were demarcated, systematically allocated with 30 meters of distance between them. Five traps were distributed in each plot, thus totaling 25 traps. Each collector was constituted by a circular iron frame, $50 \mathrm{~cm}$ in diameter $\left(0.1963 \mathrm{~m}^{2}\right.$ area), and surrounded by a 2-mm mesh, with a height of one meter from the ground (Figure $1)$.

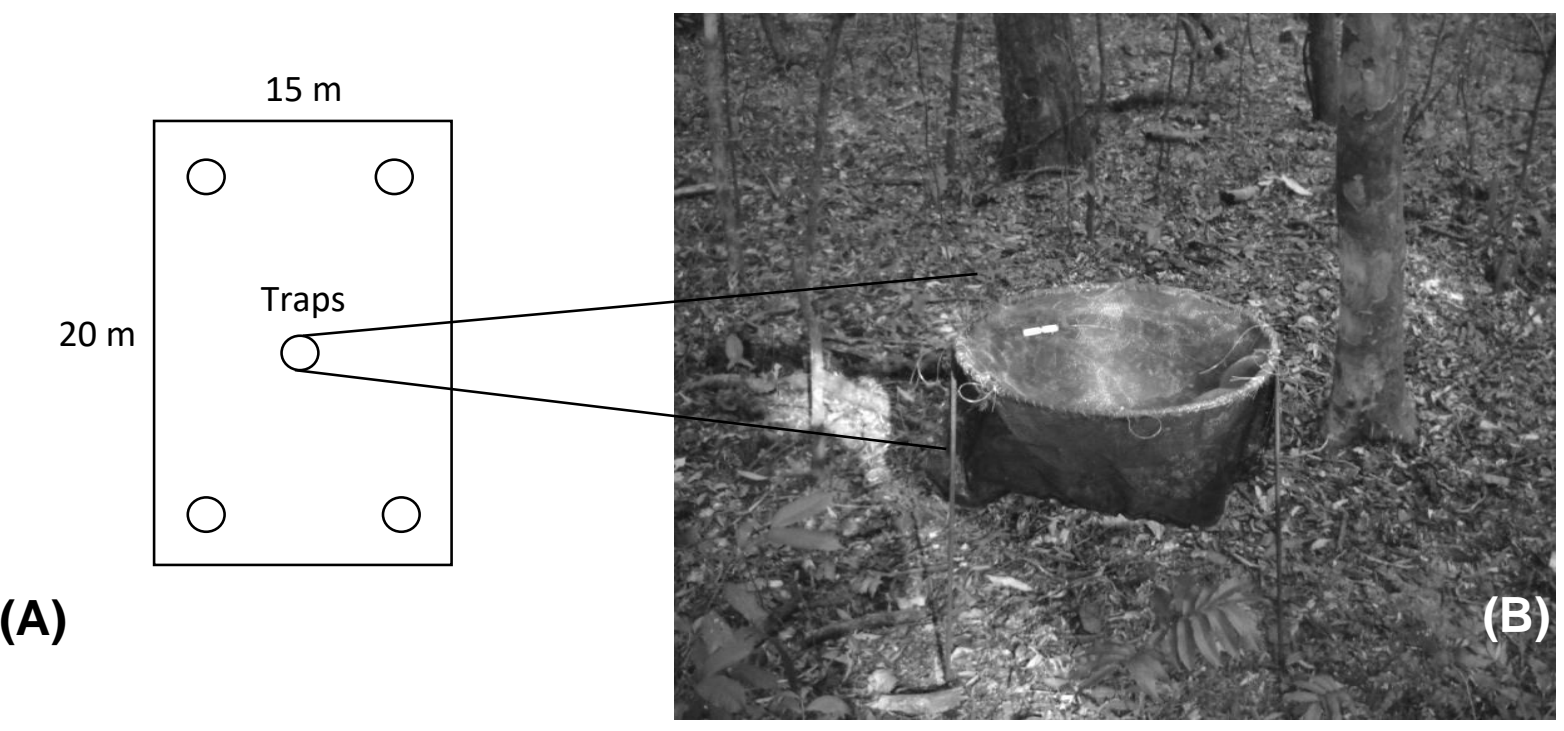

Figure 1. Sketch of one of the plots allocated in the forest with the distribution of the collectors (A). Figure of one of the litter collectors (B). Central Depression Region, RS, Brazil.

Figura 1. Croqui de uma das parcelas alocadas na floresta com a distribuição dos coletores (A). Figura de um dos coletores de serapilheira (B). Região da Depressão Central, RS, Brasil. 
The collections were carried out monthly for a period of four years, beginning in April 2013 and finishing in March 2017. In each of these collections, all the plant material deposited by the trees in the traps was removed and placed in properly identified plastic bags. The material was transported to the laboratory, where the samples were separated in leaves fractions, small twigs (diameter $<0.5 \mathrm{~cm}$ ) and miscellaneous, (fruits, flowers, seeds, bark and unidentified material), and packed in paper bags for subsequent drying in an air-circulation oven at $60^{\circ} \mathrm{C}$ until constant weight was reached. After drying, the material was weighed to obtain the dry weight. A $0.01-\mathrm{g}$ precision scale was used. As the dry weights were in grams, they were extrapolated to $\mathrm{Mg} \mathrm{ha}^{-1} \mathrm{year}^{-1}$, according to Schumacher and Viera (2015) described in Equation 1:

$$
\mathrm{LF}=\sum \frac{\mathrm{MLF} \times 10.000}{\mathrm{CA}}
$$

Where:

LF: Litterfall $\left(\mathrm{kg} \mathrm{ha}^{-1}\right.$ year $\left.^{-1}\right)$

¿MLF: Monthly litterfall $\left(\mathrm{kg} \mathrm{ha}^{-1}\right)$

CA: Collector area $\left(0.1963 \mathrm{~m}^{2}\right)$.

Pearson's simple linear correlation analysis was also performed at $5 \%$ of error probability between the dry litter weights produced and the climatic variables and total monthly rainfall and average monthly temperature. Rainfall was obtained according to data from the Mineral Resources Research Company informed by the National Water Agency (ANA) for the region of São Sepé county, State of Rio Grande do Sul. The average monthly temperature was obtained by the Meteorological Database for Teaching and Research of the National Institute of Meteorology (BDMEP / INMET) of the weather station in the municipality of São Gabriel county, State of Rio Grande do Sul RS (as it is the closest station to the experiment site, around $50 \mathrm{~km}$ from it).

\section{RESULTS}

According to Table 2, the average annual litter production in the four-year period was estimated at 6.56 $\mathrm{Mg} \mathrm{ha}^{-1}$, where the leaf-fraction represented the majority of the litterfall produced, with $67.61 \%$ of the total (varying from 62.99 to $69.70 \%$ ), followed by miscellaneous with $19.04 \%$ (ranging from 15.34 to $21.64 \%$ ) and thin branches with $13.29 \%$ (ranging from 10.39 to $17.53 \%$ ).

Table 2. Total and average litterfall production $\left(\mathrm{kg} \mathrm{ha}^{-1}\right)$ in the Semideciduous Seasonal Forest, from April 2013 to March 2017. Central Depression Region, RS, Brazil.

Tabela 2. Produção total e média de serapilheira $\left(\mathrm{kg} \mathrm{ha}^{-1}\right)$ na Floresta Estacional Semidecidual, no período de abril de 2013 a março de 2017. Região da Depressão Central, RS, Brasil.

\begin{tabular}{c|c|c|c|c}
\hline \multicolumn{5}{c}{ Year 1 (April/2013-March/2014) } \\
\hline Values in kg ha ${ }^{-1}$ & Leaves & Thin branches & Miscellaneous & Total Litterfall \\
\hline Total annual & $4,527.32(69.70 \%)^{1}$ & $674.90(10.39 \%)$ & $1,278.50(19.68 \%)$ & $6,494.97(100 \%)$ \\
Monthly average & 377.28 & 56.24 & 106.54 & 541.25 \\
Standard deviation & 232.266 & 45.30652 & 106.7111 & 315.8623 \\
\hline \multicolumn{5}{c}{ Year 2 (April/2014-March /2015) } \\
\hline Total annual & $3,876.71(64.54 \%)^{1}$ & $830.30(13.82 \%)$ & $1,299.89(21.64 \%)$ & $6,006.90(100 \%)$ \\
Monthly average & 323.06 & 69.19 & 108.32 & 500.57 \\
Standard deviation & 172.8157 & 37.92572 & 86.33939 & 314.8026 \\
\hline \multicolumn{5}{c}{ Year 3 (April/2015-March/2016) } \\
\hline
\end{tabular}

FLORESTA, Curitiba, PR, v. 51, n. 1, p. 019-027, jan/mar 2021.

Vogel, H. L. M. et.al.

ISSN eletrônico 1982-4688

DOI: $10.5380 /$ rf.v51 i1. 64443 


\begin{tabular}{|c|c|c|c|c|}
\hline Monthly average & 391.51 & 108.99 & 121.07 & 621.57 \\
\hline Standard deviation & 126.5854 & 109.3488 & 71.7382 & 323.8257 \\
\hline \multicolumn{5}{|c|}{ Year 4 (April/16-March /2017) } \\
\hline Total annual & $4,601.69(73.23 \%)^{1}$ & $718.30(11.43 \%)$ & $964.31(15.34 \%)$ & $6,284.30(100 \%)$ \\
\hline Monthly average & 383.47 & 59.86 & 80.36 & 523.69 \\
\hline Standard deviation & 247.9049 & 58.39535 & 83.4291 & 311.4739 \\
\hline Total 4 years & $17.703,82(67,46 \%)^{1}$ & $3.531,36(13,45 \%)$ & $4.995,56(19,03 \%)$ & $26,244.99(100 \%)$ \\
\hline Average 4 years & $4,425.95$ & 882.84 & $1,248.89$ & $6,561.25$ \\
\hline
\end{tabular}

${ }^{1}$ Values in parentheses refer to the percentage of the total.

It is observed in Table 2 that a greater annual production of litterfall occurred between April/2015 to March/ 2016. A decrease is seen in the total litterfall production in the second year (April/2014 to March/2015), with the highest production in the third year, and again, a decrease in the fourth year. Regarding the litter seasonality (Figure 2), it is observed that from October 2013 to December 2013 there was a significant increase in litterfall deposition, with a peak deposition in November in the first year of assessment. In the second year, the peak deposition occurred from August 2014 to December in the same year. In the third year, there is also a large deposition in September and October, but with a great increase in February. In the fourth year, there was a high peak of devolution in October, demonstrating that the greatest litterfall deposition occurred in October and November, due to the growth resumption with the renewal of the canopy. The lowest depositions occurred in February.

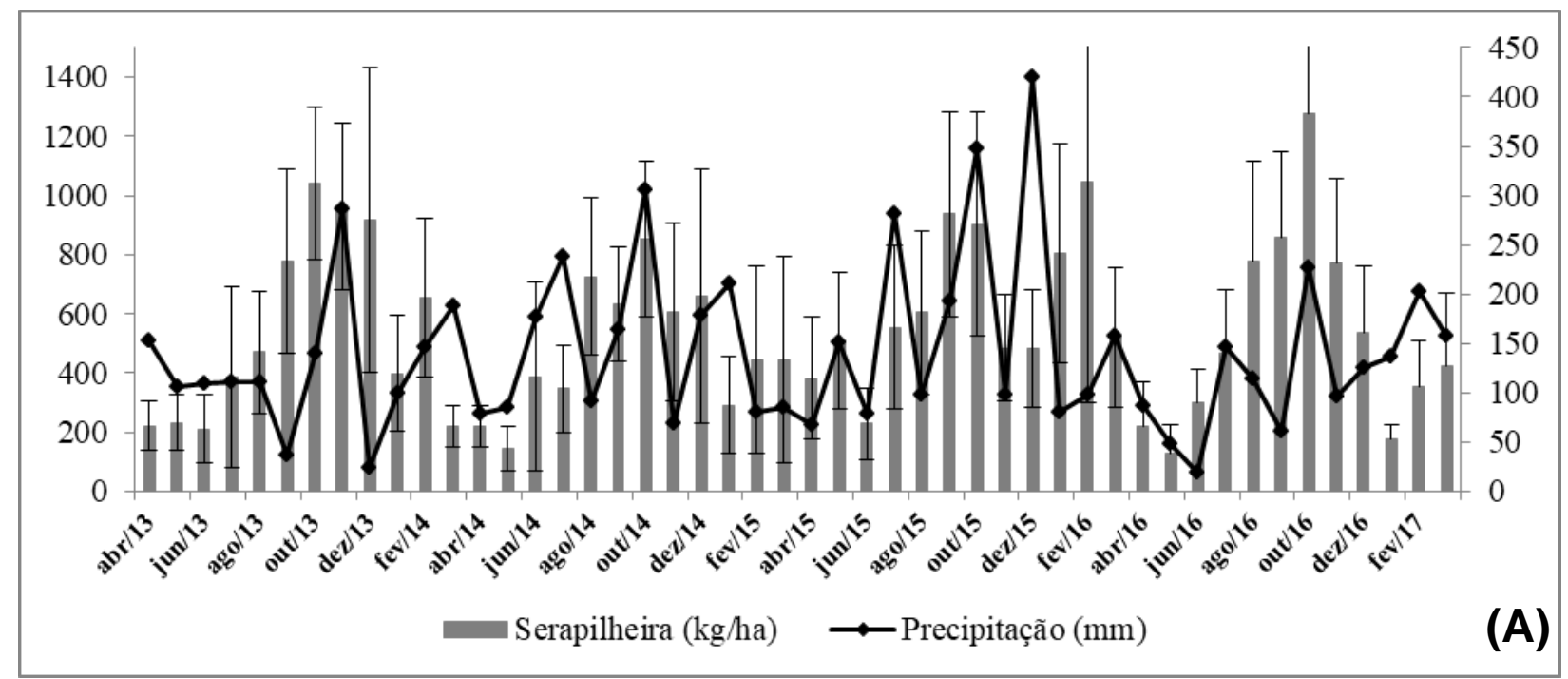

FLORESTA, Curitiba, PR, v. 51, n. 1, p. 019-027, jan/mar 2021.

Vogel, H. L. M. et.al. 


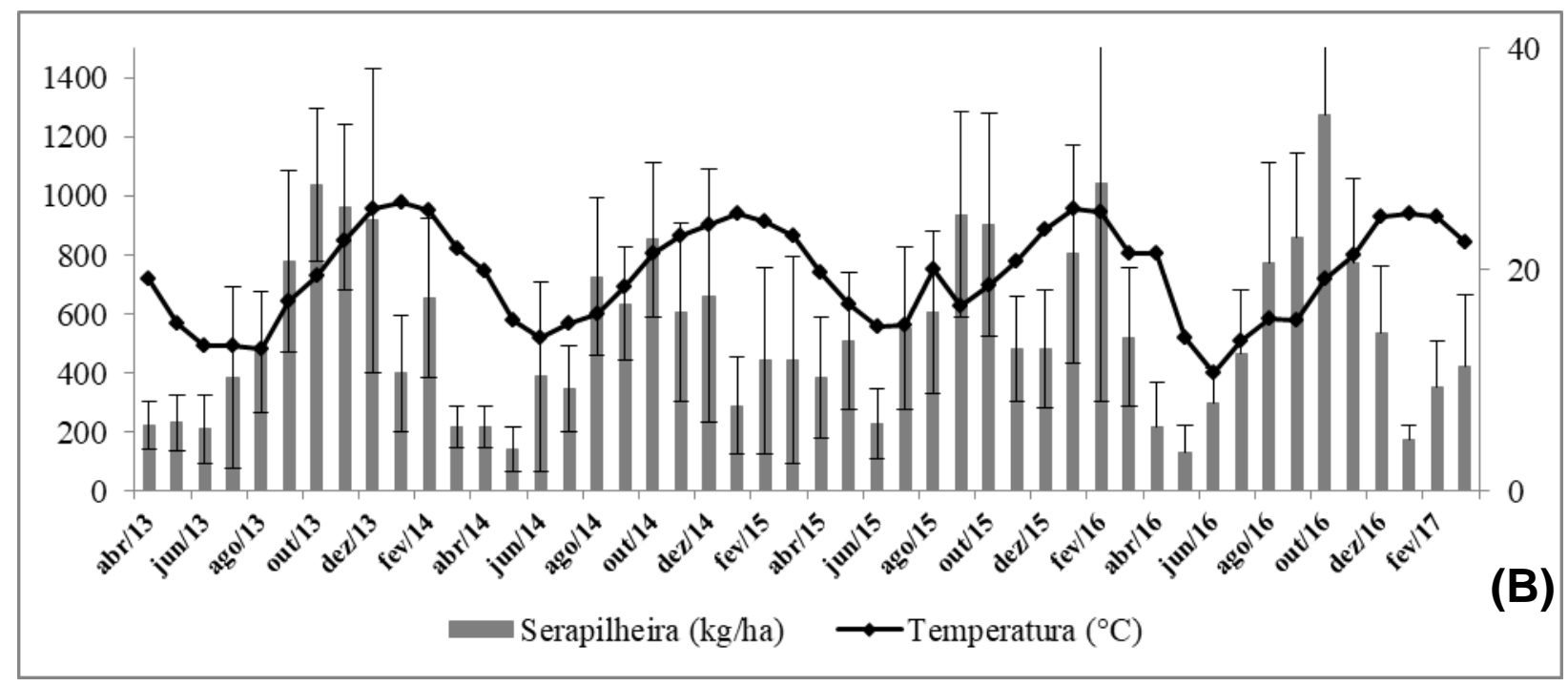

Figure 2. Litter seasonality and total monthly rainfall (A) and monthly average temperature (B) over four years, in the Semideciduous Seasonal Forest. Region of Central Depression, RS, Brazil. Vertical lines represent data dispersion.

Figura 2. Sazonalidade da serapilheira e precipitação total mensal (A) e temperatura média mensal (B) ao longo de quatro anos, na Floresta Estacional Semidecidual. Região da Depressão Central, RS, Brasil. Linhas na vertical representam a dispersão dos dados.

Table 3 shows the correlation between the climatic variables, monthly rainfall and average temperature with the litterfall deposition and its fractions. It can be seen in this Table that only a significant correlation was obtained between the thin branches and the miscellaneous with the average temperature.

Table 3. Pearson's correlation coefficients between the components of the Seasonal Semideciduous Forest litter and climatic variables. Region of Central Depression, RS, Brazil.

Tabela 3. Coeficientes de correlação de Pearson, entre os componentes da serapilheira da Floresta Estacional Semidecidual e as variáveis climáticas. Região da Depressão Central, RS, Brasil.

\begin{tabular}{c|c|c|c|c}
\hline Climatic variables & Leaves & Thin branches & Miscellaneous & Litterfall \\
\hline Monthly rainfall & $0.171^{n . s .}$ & $0.142^{\text {n.s. }}$ & $0.229^{\text {n.s. }}$ & $0.224^{\text {n.s. }}$ \\
& $(P=0.244)$ & $(P=0.337)$ & $(P=0.117)$ & $(P=0.126)$ \\
\hline \multirow{2}{*}{ Average monthly temperature } & $-0.0814^{n . s .}$ & $0.339^{*}$ & $0.616^{*}$ & $0.217^{n . s .}$ \\
& $(P=0.582)$ & $(P=0.0184)$ & $(P=0.00000315)$ & $(P=0.138)$ \\
\hline
\end{tabular}

Where: n.s. = non-significant $(\mathrm{P}>0.050) ; *$ significant $(\mathrm{P}<0.050)$.

\section{DISCUSSION}

According to Table 2, over the four experimental years, the litterfall production in this study was usually close to that found by other authors in the southern region of Brazil, such as that by Vogel et al. (2007), in a Seasonal Deciduous Forest in Itaara county-RS, where a litterfall production of $8.40 \mathrm{Mg} \mathrm{ha}^{-1}$ was observed in 2003 and a lower production of $6.46 \mathrm{Mg} \mathrm{ha}^{-1}$ in 2004. Schumacher et al. (2011), when evaluating the litter production in the same place, in the period from 2006 to 2007, obtained an average production of $6.3 \mathrm{Mg} \mathrm{ha}^{-1}$ in 2006 and $5.41 \mathrm{Mg} \mathrm{ha}^{-1}$ in 2007. The litterfall production of this typology varies between 5.8 and $8.1 \mathrm{Mg} \mathrm{ha}^{-1}$ year $^{-1}$ (SCHUMACHER et al., 2018) and $5.1 \mathrm{Mg} \mathrm{ha}^{-1}$ year $^{-1}$ (DICK et al., 2015) was observed in Deciduous Seasonal Forest in southern Brazil. When assessing a litterfall production in a seasonal deciduous forest in the municipality of Santa Maria county-RS, König et al. (2002) found a litterfall production of $9.2 \mathrm{Mg} \mathrm{ha}^{-1} \mathrm{year}^{-1}$, formed by $67.8 \%$ of leaves, $19.3 \%$ by thin branches $(<1 \mathrm{~cm}$ in diameter) and $12.9 \%$ by miscellaneous (flowers, fruits, seeds, other plant materials).

FLORESTA, Curitiba, PR, v. 51, n. 1, p. 019-027, jan/mar 2021. 
These works demonstrate the great variability of deposition over the years, with years of greater deposition and years of less deposition, a fact that was observed in this study. Many studies report that litterfall production in native forest can also be strongly related to the development stage, such as the work of Menezes $e t$ al. (2010), who evaluated different successional stages in Pinheiral county in the State of Rio de Janeiro, found values of $6.6,7.4$ and $11 \mathrm{Mg} \mathrm{ha}^{-1}$ year $^{-1}$ for forest in the early stage, medium stage and advanced stage, respectively. Pinto et al. (2009), in two stretches of Seasonal Semideciduous Forest, in different successional stages (initial and mature), in the region of Viçosa county, State of Minas Gerais, found that the annual litterfall production was $6.31 \mathrm{Mg} \mathrm{ha}^{-1}$ year $^{-1}$ in the forest stretch in its initial stage and $8.82 \mathrm{Mg} \mathrm{ha}^{-1}$ year ${ }^{-1}$ in the advanced stage. Pereira et al. (2008), in a hillside fragment of the Atlantic Forest on Marambaia Island, Mangaratiba county State of Rio de Janeiro, found a litterfall production of $7.9 \mathrm{Mg} \mathrm{ha}^{-1}$ year ${ }^{-1}$, with the highest deposition observed in November and the lowest in June; according to the authors, the leaf fraction was the major contributor in relation to the others with $66 \%$.

According to the regeneration stage of the forest, litterfall deposition can vary, as shown by the study by Barlow et al. (2007) in the northeastern Brazilian Amazon, where they registered a contribution of $7.8 \mathrm{Mg} \mathrm{ha}^{-}$ ${ }^{1}$ year $^{-1}$ in the primary forest, and $6.8 \mathrm{Mg} \mathrm{ha}^{-1}$ year $^{-1}$ in the secondary forest at 14 to 19 years of regeneration. In western Paraná, in a seasonal semideciduous forest fragment, the annual litterfall production was $11.89 \mathrm{Mg}$ ha $^{-1}$ (Toscan et al., 2017), which is well above that found in the present study. The authors also report that August and September were the months of greatest production, with the leaf fraction representing $8.52 \%$ of the total. According to the results in Figure 2, there is a greater deposition between September and November.

In relation to the seasonality of litterfall deposition, it is observed in Figure 2, a similar seasonal behavior in the assessed four-year period, with greater litterfall deposition mainly in the spring season (particularly in in October followed by November). This seasonal behavior can be attributed to the resumption of tree growth, which, as a result, renew their crowns and consequently deposit large amounts of senescent leaves in this period, typical of seasonal subtropical forests. The lowest deposition rates occurred in April, May and June, when plant growth was reduced due to the decrease in temperature, as shown by some studies, such as König et al. (2002); Schumacher et al. (2018) and Dick et al. (2015). This annual variation can be related to environmental conditions, which can influence a greater or lesser annual production.

Cunha et al. (1993) in a forest of the same typology in Santa Maria county, State of Rio Grande do Sul found the largest yields in the spring period between August and November, due to the increase in rainfall rate and temperatures, and the lower production corresponding to the months of autumn. König et al. (2002), also in Seasonal Deciduous Forest, close to Santa Maria county, Rio Grande do Sul state, found that the greatest peaks of litterfall deposition occurred between July and September, with the greatest fall of leaves in September, when temperature starts to rise. The authors also emphasize that such a strategy is characteristic of the Deciduous Seasonal Forests of southern Brazil, in which a stagnation of growth caused by winter results in the elimination of senescent foliage, aiming at the new growth period, which begins with spring, with the appearance of new foliage, a fact also observed in the present study. A greater deposition of litterfall in the spring was also observed by Figueiredo Filho et al. (2003), in a mixed rainforest in southern Paraná.

The differences found in these works reflect the great influence of the place and the type of forest formation, being influenced mainly by the climate and soils of the region, among other ecological factors. Regarding the soil of the study site, according to Table 1, it can be considered with a sandy-loam surface texture and low organic matter content, low P levels, average K, Ca and Mg levels (CQFS, 2016), decreasing with the depth, which characterizes it as of medium to low fertility, being able to influence in a lesser production of litter due to the smaller size of the treetops.

Regarding the climatic variables (temperature and precipitation), it can be seen in Figure 2 that in relation to the average monthly temperature, an increase in the deposition of litterfall is observed as temperature increases, and a decrease as the temperatures decrease. Figure 2 also shows a slight trend between the rainiest months and the increase in litterfall deposition. However, there was a low, non-significant correlation with leaf deposition and these climatic variables (Table 3). There was only a significant high correlation between the miscellaneous and temperature, followed by thin branches, as shown in Table 3, indicating the influence of temperature on the production of reproductive material, such as flowers, fruits and seeds.

Similar results were obtained by Vogel et al. (2007), in a Seasonal Deciduous Forest in Itaara county in the central region of Rio Grande do Sul State. The authors also found a significant correlation between the miscellaneous fraction and the average temperature, but they did not find a significant correlation between the fractions of leaves and thin branches with the average temperature and monthly precipitation. In another study in Deciduous Seasonal Forest in the region of Santa Maria county, Rio Grande do Sul State, König et al. (2002) found that the deposition of the fractions of leaves and thin branches, and the total litterfall showed significant negative correlations with temperature, not being significantly correlated with rainfall. Figueiredo Filho et al.

FLORESTA, Curitiba, PR, v. 51, n. 1, p. 019-027, jan/mar 2021.

Vogel, H. L. M. et.al.

ISSN eletrônico 1982-4688

DOI: 10.5380/rf.v51 i1. 64443 
(2003) obtained a low non-significant correlation with temperature and rainfall, in a mixed rainforest in southern Paraná. An explanation for the low non-significant correlations of this study between deposition and rainfall may be the great variability in the fall of leaves, branches and miscellaneous over the months, which is also influenced by other climatic factors, such as winds, hail, among others, making it difficult to state which climatic variable can influence litterfall deposition the most.

Another important aspect to be highlighted is related to the location from where the climatic information is collected, which may have influenced the correlation results, as also reported by Figueiredo Filho et al. (2003) in his study with litterfall, which emphasizes that the ideal situation would be the availability of a station at the experimental site and the continuity of the research over a longer period, which will probably be able to bring more solid information regarding the correlation with climatic variables.

\section{CONCLUSION}

- In the four years of collection, there was a greater deposition of litterfall in the spring, with the highest deposition peaks mainly in October, indicating a seasonal deposition behavior.

- An average annual deposition of $6.56 \mathrm{Mg} \mathrm{ha}^{-1} \mathrm{year}^{-1}$ of litterfall was observed in the assessed period; of this total, the leaves accounted for $67.61 \%$, followed by the miscellaneous with $19.04 \%$ and the thin branches with $13.29 \%$.

- The production of leaves represents a great organic contribution, indicating to be the main route of nutrients entry into the soil.

- Environmentally at the local level, the climatic variables temperature and precipitation indicate an influence on litterfall deposition, but only a significant high correlation was obtained between the miscellaneous fraction and the average monthly temperature.

\section{ACKNOWLEDGEMENTS}

To the Academic Development Program-PDA of UNIPAMPA for granting the scientific initiation scholarship in the studied period.

\section{REFERENCES}

AlVARES, C. A.; STAPE, L.; SENTElHAS, P. C.; GONÇALVES, L. D. M.; SPAROVEK, G. Köppen's climate classification map for Brazil. Meteorologische Zeitschrift, Stuttgart, v. 22, n. 6, p. 711 - $28,2014$.

BRAY, J. R.; GORHAM, E. Litter production in forests of the world. Advances in Ecological Research, Londres, v. 2, p. 101 - 157, 1964.

BARLOW, J.; GARDNER, T. A.; LEANDRO, L. V.; PERES, C. A. Litter fall and decomposition in primary, secondary and plantation forests in the Brazilian Amazon. Forest Ecology and Management, Amsterdam, v. 247, p. 91 - 97, 2007.

CALVI, G. P.; PEREIRA, M. G.; ESPÍNDULA JÚNIOR, A. Produção de serapilheira e aporte de nutrientes em áreas de Floresta Atlântica em Santa Maria de Jetibá, ES. Ciência Florestal, Santa Maria, v. 19, n. 2 , p. 131 138, 2009.

COMISSÃO DE QUÍMICA E FERTILIDADE DO SOLO - CQFS. Manual de adubação e calagem para os estados do Rio Grande do Sul e de Santa Catarina. Porto Alegre: Sociedade Brasileira de Ciência do Solo, 11 ed. 2016, $376 \mathrm{p}$.

CUNHA, G. C.; GRENDENE, L. A.; DURLO, M. A.; BRESSAN, D. A. Dinâmica nutricional em floresta Estacional Decidual com ênfase ao minerais provenientes da deposição da serapilheira. Ciência Florestal, Santa Maria, v. 3, n. 1, p. 35 - 64, 1993.

DICK G, D’ÁVILA M, SCHUMACHER MV. Produção de serapilheira em fragmento de Floresta Estacional Subtropical na região norte do Rio Grande do Sul. Ecologia e Nutrição Florestal, Santa Maria, v. 3, n. 1, p. 1 8,2015 .

EMPRESA BRASILEIRA DE PESQUISA AGROPECUÁRIA - EMBRAPA. Sistema brasileiro de classificação de solos. Brasília: Embrapa Solos, 5 ed. 2018, 355 p.

FLORESTA, Curitiba, PR, v. 51, n. 1, p. 019-027, jan/mar 2021.

Vogel, H. L. M. et.al.

ISSN eletrônico 1982-4688

DOI: $10.5380 /$ rf.v51 i1. 64443 
FIGUEIREDO FILHO, A.; MORAES, G. F.; SCHAAF, L. B.; FIGUEIREDO, D. J. Avaliação estacional da deposição de serapilheira em uma floresta ombrófica mista localizada no sul do estado do Paraná. Ciência Florestal, Santa Maria, v. 13, n. 1, p.11 - 18, 2003.

INSTITUTO NACIONAL DE METEOROLOGIA - INMET. Dados meteorológicos. Disponível: <http://www.inmet.gov.br/>Acesso em: 15/12/2018.

KÖNIG, F. G.; SCHUMACHER, M. V.; BRUN, E. J.; SELING, I. Avaliação da sazonalidade da produção de serapilheira numa floresta Estacional Decidual no município de Santa Maria-RS. Revista Árvore, Viçosa, v. 26, n. 4, p. $429-435,2002$.

LORENZO, L.; CAMPAGNARO, V. H. Litterfall production as a function of planting seedlings system in a two years forest restoration area in the coastalplain of Caraguatatuba, São Paulo, Brazil. Revista Árvore, Viçosa, v. 41, n. 3, p. $1-8,2017$.

MENEZES, C. E. G.; PEREIRA, M. G.; CORREIA, M. E. F.; ANJOS, L. H. C.; PAULA, R. R.; SOUZA, M. E. Aporte e decomposição da serapilheira e produção de biomassa radicular em florestas com diferentes estágios sucessionais em Pinheiral, RJ. Ciência Florestal, Santa Maria, v. 20, n. 3, p. 439 - 452, 2010.

NASCIMENTO, A. F. J.; SILVA, T. O.; ARAÚJO FILHO, R. N.; SAMPAIO, E. V. de S. B.; PEDROTTI, A.; GONZAGA, M. I. S.; PISCOYA, V. C. Produção e aporte de carbono, nitrogênio e fósforo na serapilheira foliar do Parque Nacional Serra de Itabaiana. Ciência Florestal, Santa Maria, v. 28, n. 1, p. 35 - 46, 2018.

PEREIRA, M. G.; MENEZES, L. F.; SCHULTZ, N. Aporte e decomposição da serapilheira na floresta Atlântica, ilha da Marambaia, Mangaratiba, RJ. Ciência Florestal, v. 18, n. 4, p. 443 - 454, 2008.

PINTO, S.I.C.; MARTINS, S. V.; BARROS, N. F.; DIAS, H. C. T. Ciclagem de nutrientes em dois trechos de Floresta Estacional Semidecidual na reserva florestal Mata do Paraíso em Viçosa, MG, Brasil. Revista Árvore, Viçosa, v. 33, n. 4, p. 653 - 663, 2009.

RIBEIRO, M. C.; METZGER, J. P.; MARTENSEN, A. C.; PONZONI, F. J.; HIROTA, M. M. The Brazilian Atlantic Forest: How much is left, and how is the remaining forest distributed? Implications for conservation. Biological Conservation, Amsterdam, v. 142, p. 1141 - 1153, 2009.

SCHUMACHER, M. V.; TRÜBY, P.; MARAFIGA, J. M.; VIEIRA, M.; SZYMCZAK, D. A. Espécies predominantes na deposição de serapilheira em fragmento de floresta estacional decidual no Rio Grande do Sul. Ciência Florestal, Santa Maria, v. 21, n. 3, p. 479 - 486, 2011.

SCHUMACHER, M. V.;VIERA, M. Ciclagem de nutrientes em plantações de eucalipto. In: SCHUMACHER, M. V.; VIERA, M. Silvicultura do Eucalipto no Brasil. Santa Maria: Editora UFSM, 2015, 319 p.

SCHUMACHER, M. V.; SZYMCZAK, D. A;; TRÜBY, P.; LONDERO, E. K; MARAFIGA, J. Aporte de serapilheira e nutrientes em uma Floresta Estacional Decidual na região central do Rio Grande do Sul. Ciência Florestal, Santa Maria, v. 28, n. 2, p. $532-541,2018$.

TEDESCO M. J.; GIANELlO, C.; BISSANI, C. A.; BOHNEN, H.; VOLKWEISS, S. J. Análise de solo, plantas e outros materiais. Porto Alegre: UFRGS; 1995. 118 p. (Boletim técnico).

TOSCAN, M. A.; GUIMARÃES, A. B.; TEMPONI, L. G. Caracterização da produção de serapilheira e da chuva de sementes em uma reserva de Floresta Estacional Semidecidual, Paraná. Ciência Florestal, Santa Maria, v. 27, n. 2, p. 415 - 427, 2017.

VIERA, M.; CALDATO, S. L.; ROSA, S. F.; KANIESKI, M. R.; ARALDI, D. B.; SANTOS, S. R.; SCHUMACHER, M. V. Nutrientes na serapilheira em um fragmento de floresta Estacional Decidual, Itaara, RS. Ciência Florestal, Santa Maria, v. 20, n. 4, p. 611 - 619, 2010.

VITAL, A. R. T.; GERRINE, I. A.; FRANKEN, W. K.; FONSECA, R. C. B. Produção de serapilheira e ciclagem de nutrientes de uma floresta estacional semidecidual em zona riparia. Revista Árvore, Viçosav. 28, n. 6, p. $793-800,2004$.

VOGEL, H. L. M.; SCHUMACHER, M. V.; TRÜBY, P. Avaliação da devolução de serapilheira em uma floresta Estacional Decidual, em Itaara, RS, Brasil. Ciência Florestal, Santa Maria, v. 17, n. 3, p. 187 - 196 , 2007.

FLORESTA, Curitiba, PR, v. 51, n. 1, p. 019-027, jan/mar 2021.

Vogel, H. L. M. et.al.

ISSN eletrônico 1982-4688

DOI: $10.5380 /$ rf.v51 i1. 64443 